\title{
CITRA PRODUK NEGARA DALAM MEMPENGARUHI PILIHAN KONSUMEN TERHADAP PRODUK DENGAN VARIABEL MODERASI HARGA
}

\author{
Rendy Ramadhiansa \\ Program Studi Magister Manajemen Universitas Tarumanagara \\ rendy.rr93@gmail.com
}

\begin{abstract}
This research aims to test consumers' perception towards products produced in developing countries similar to products produced in developed countries. In particular, this research will focus on the role of price moderation as moderator variable in the relation between country's image and product preference by consumers in Indonesia. The framework in this research would be using country product image as independent variable, price as moderating variable, which both would affect product preference as dependent variable. Method used in this research is multiple linear analysis. The outcome of this research is that both country product image and price positively affects product selection.
\end{abstract}

Keywords : Country Product Image, Product Preference, Price

\section{PENDAHULUAN}

Pada era ini perkembangan teknologi dan informasi sangat pesat sehingga menyebabkan persaingan smartphone menjadi semakin ketat karena smartphone sudah merupakan kebutuhan komunikasi utama yang wajib dimiliki oleh semua masyarakat dari berbagai kalangan. Beredarnya merek smartphone yang berasal dari berbagai Negara dengan karakteristik, fitur, dan harga yang beragam membuat konsumen semakin selektif memilih produk smartphone yang sesuai dengan keinginan mereka. Untuk memenuhi kebutuhannya maka konsumen akan memilih suatu produk sesuai dengan keinginannya. Dalam menentukan pilihan produk biasanya konsumen melihat dari harga produk tersebut dan juga citra produk Negara tersebut.

Citra Negara dipersepsikan sebagai efek yang muncul dalam persepsi konsumen terhadap negara suatu merek atau produk. Keyakinan stereotype yang diasosiakan dengan negara asal telah menyebabkan beberapa orang peneliti menerapkan prinsip kategorisasi terhadap pemrosesan informasi negara asal. Konsumen mampu membentuk ikatan mereka ketika memikirkan tentang negara, seperti Perancis dengan fashion, Korea Selatan dengan teknologi komunikasi tinggi, Tiongkok dengan berbagai produk murah (Andriani, 2015).

Pada masa ini, smartphone sudah bukan barang yang asing. Ia sudah melekat ke dalam sendi kehidupan masyarakat modern. Hampir semua kebutuhan kian terbantu berkat benda ini, mulai dari pemenuhan kebutuhan informasi, bekerja, memesan makanan, liburan, dan lain sebagainya. Semuanya bisa selesai dengan satu tap saja. (https://id.techinasia.com diakses pada 30 April 2018).

Berdasarkan sudut pandang country product image, produk buatan China dan Korea memang bersaing ketat di pangsa pasar Indonesia terutama untuk produk smartphone. Adanya perbedaan persepsi konsumen terhadap merek smartphone yang di produksi oleh perusahaan dari suatu negara merupakan suatu fenomena yang terjadi saat ini. (Fardan, 2016)

Dalam penelitian ini mengambil sampel satu produk dari Negara berkembang, dan satu produk dari Negara maju. Produk yang digunakan pada penelitian ini adalah smartphone OPPO dari Negara berkembang China dan Samsung dari Negara Korea Selatan.

\section{Pokok Masalah}


Berdasarkan latar belakang masalah yang telah diuraikan di atas maka dapat diambil rumusan masalah sebagai berikut :

a. Bagaimana persepsi konsumen terhadap suatu produk serupa yang dihasilkan oleh negara maju dan negara berkembang?

b. Bagaimana pengaruh citra negara dapat mempengaruhi pilihan konsumen atas suatu produk?

c. Bagaimana pengaruh harga dalam mempengaruhi pilihan konsumen terhadap suatu produk?

\section{TELAAH KEPUSTAKAAN}

\section{Country Product Image}

Menurut Han, Citra produk Negara adalah persepsi umum tentang kualitas produk yang dibuat di suatu negara. Country Product Image memiliki peran penting dalam konteks evaluasi produk dari Negara berkembang karena citra negara telah terbukti mempengaruhi kepercayaan produk dan evaluasi produk konsumen. Secara umum, produk dari negara maju mendapat nilai positif dari konsumen dibandingkan produk yang berasal dari negara-negara kurang berkembang. Dikatakan bahwa konsumen di negara maju cenderung memilih produk dari negara mereka sendiri terlebih dahulu, mengikuti produk dari negara maju lainnya, dan kemudian baru produk dari negara berkembang.

\section{Product Preference}

Menurut Kotler (2008), preferensi konsumen terbentuk melalui variabel-variabel kebiasaan, kecenderungan, dan kesesuaian terhadap berbagai variasi produk atau pemasok yang tersedia. Preferensi konsumen dapat dijelaskan sebagai suatu sikap konsumen terhadap satu pilihan merek produk maupun pemasok yang terbentuk melalui proses evaluasi.

\section{Harga}

Kotler dan Amstrong (2011) menyebutkan bahwa harga adalah sejumlah uang yang diberikan atas suatu produk, atau jumlah dari nilai yang ditukar konsumen atas manfaat karena memiliki atau menggunakan produk itu. Harga merupakan salah satu faktor penentu dalam pemilihan merek yang berkaitan dengan pilihan konsumen. Ketika memilih diantara merek yang ada, konsumen akan mengevaluasi harga dengan membandingkan beberapa standar harga sebagai referensi untuk melakukan transaksi pembelian.

\section{Kerangka Berpikir}

Kerangka berpikir hipotesis dari penelitian ini adalah dengan menggunakan country product image sebagai variabel independen, harga sebagai variabel moderasi dimana keduanya mempengaruhi product preference sebagai variabel dependen. Kerangka berpikir hipotesis dapat dilihat pada Gambar 1 dibawah ini.

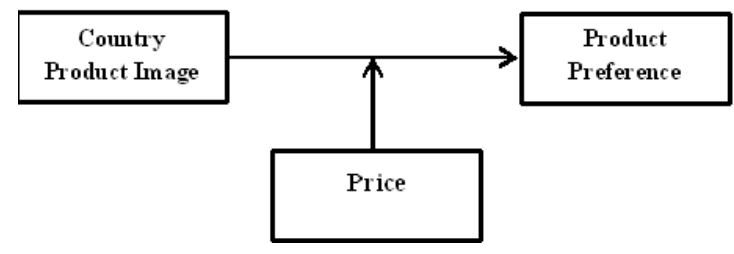

\section{Gambar 1. Kerangka berpikir}

Dari Gambar 1 diatas, dapat dijelaskan bahwa Country Product Image merupakan suatu faktor yang dapat mempengaruhi product preference konsumen dan harga merupakan suatu faktor yang dapat memperkuat/memperlemah product preference tersebut.

\section{Hubungan Country Product Image dengan Product Preference}

Country product image merupakan persepsi konsumen terhadap semua produk yang dihasilkan oleh suatu Negara. Persepsi tersebut dapat berupa inovatif produk, prestige produk 
dan kehandalan produk. Dari gambar diatas dapat dilihat bahwa product preference dapat dipengaruhi oleh country product image. Sebagian orang dalam memilih suatu produk ada yang melihat produk itu dari citra Negara pembuatan produk tersebut. Sebagian orang berpendapat bahwa produk dari Negara maju lebih baik kualitasnya dibandingkan produk dari Negara berkembang.

\section{Hubungan Harga dengan Product Preference}

Menurut David (2014), harga merupakan elemen penting yang utama dalam penjualan suatu produk dan konsumen harus menerimanya. Oleh karena itu, sangat penting untuk mengetahui penggunaan konsep, kriteria dan taktik yang dikembangkan untuk menetapkan kebijakan harga yang harus diikuti dalam penjualan internasional untuk mendapat kinerja yang maksimal. Salah satu hal yang sangat penting dalam pemilihan produk terhadap suatu produk atau jasa adalah harga. Harga seringkali membantu dalam pemilihan produk oleh konsumen.

\section{Peran Moderasi Harga}

Bidang penelitian dalam penelitian ini berfokus pada kemungkinan variabel moderasi yang mempengaruhi hubungan antara citra negara dan evaluasi produk. Wyer dan Hong , menemukan bahwa efek negara asal pada evaluasi produk dipengaruhi oleh selang waktu sejak informasi negara asal disampaikan kepada konsumen. Peterson dan Jolibert menyarankan perlunya melihat variabel moderasi yang lebih penting untuk memahami lebih jelas dampak efek Negara asal. Hal ini penting dari sudut pandang sifat dinamis negara asal. Negara-negara seperti Korea Selatan dan Taiwan yang pernah dianggap sebagai bagian dari negara-negara berkembang telah masuk dalam daftar negara maju (Mehmet et al, 2010).

\section{Metode Penelitian}

Jenis penelitian yang digunakan dalam penelitian ini merupakan jenis penelitian kuantitatif. Penelitian ini bertujuan untuk menentukan citra produk Negara dalam mempengaruhi pilihan konsumen atas suatu produk dengan variabel moderasi harga. Periode penelitian dilakukan dari bulan Mei 2017 sampai dengan Mei 2018.

\section{Metode Analisis} reliabilitas.

Metode analisis yang akan digunakan pada penelitian ini adalah uji validitas dan uji

\section{Uji Validitas}

Sugiyono (2014) mengemukakan bahwa: "Untuk mengetahui valid tidak suatu instrumen penelitian, bila harga korelasi setiap item instrumen di bawah 0.30, maka dapat disimpulkan bahwa butir instrumen tersebut tidak valid, sehingga harus diperbaiki atau dibuang." Salah satu hasil uji validitas dapat dilihat pada Tabel 1 dibawah ini.

Tabel 1

Hasil Uji Validitas variabel Country Image produk Samsung

\begin{tabular}{|c|c|c|}
\hline No Item & Koefisien Korelasi & Hasil \\
\hline CI1.S & 0,689 & VALID \\
\hline CI2.S & 0,832 & VALID \\
\hline CI3.S & 0,852 & VALID \\
\hline CI4.S & 0,846 & VALID \\
\hline CI5.S & 0,683 & VALID \\
\hline
\end{tabular}

Sumber: Hasil pengolahan data menggunakan SPSS 
Berdasarkan Tabel 1 diatas didapat bahwa hasil dari koefisien korelasi untuk semua butir pertanyaan lebih dari 0,30. Dengan demikian dihasilkan kesimpulan bahwa semua pernyataan country image untuk responden Samsung adalah valid.

\section{Uji Reliabilitas}

Uji reliabilitas pada penelitian ini dilihat dari Cronbach's Coefficient Alpha. Instrumen akan dikatakan reliable jika nilai Cronbach's Coefficient Alpha > 0,6. Berikut adalah hasil uji reliabilitas yang telah dilakukan dengan menyebarkan kuesioner uji coba secara online kepada 30 responden Samsung dan 30 responden Oppo. Salah satu hasil uji reliabilitas dapat dilihat pada Tabel 2 dibawah ini.

Tabel 2

Hasil Uji Reliabilitas

Variabel CI Samsung

Reliability Statistics

\begin{tabular}{|r|r|}
\hline $\begin{array}{c}\text { Cronbach's } \\
\text { Alpha }\end{array}$ & N of Items \\
\hline .839 & 5 \\
\hline
\end{tabular}

Dari Tabel 2 disamping dapat dilihat Country Image menghasilkan nilai Cronbach's Coefficient Alpha sebesar 0,839 untuk Responden Samsung Hasil tersebut lebih besar dari 0,6 maka dihasilkan kesimpulan bahwa variabel Country Image reliable

Sumber: Hasil pengolahan data menggunakan SPSS

\section{Uji Asumsi Klasik}

Uji asumsi klasik yang digunakan pada penelitian ini adalah uji normalitas, uji multikolinieritas dan uji heteroskedastisitas.

Tabel 3. Hasil Uji Normalitas Samsung

\section{One-Sample Kolmogorov-Smirnov Test}

\begin{tabular}{|ll|r|}
\hline & & $\begin{array}{r}\text { Unstandardize } \\
\text { d Residual }\end{array}$ \\
\hline $\mathrm{N}$ & Mean & 200 \\
Normal & Std. & .0000000 \\
Parameters & \\
& Deviation & .41247773 \\
Most Extreme & Absolute & .088 \\
Differences & Positive & .088 \\
& Negative & -.067 \\
Kolmogorov-Smirnov Z & 1.238 \\
Asymp. Sig. (2-tailed) & .093 \\
\hline a. Test distribution is Normal. & \\
\hline
\end{tabular}

Sumber: Hasil pengolahan data menggunakan SPSS
Dari Tabel 3 disamping, dapat dilihat hasil uji normalitas produk Samsung dengan uji Kolmogrov-Smirnov Test untuk produk Samsung yaitu 0,093>0,05. Sehingga dapat disimpulkan bahwa data berdistribusi dengan normal. 
Tabel 4. Hasil Uji Multikolinieritas Uji Multikolinieritas pada produk Samsung

\begin{tabular}{|ll|r|r|}
\hline \multirow{2}{*}{ Model } & \multicolumn{2}{|c|}{ Collinearity Statistics } \\
\cline { 2 - 4 } & Tolerance & \multicolumn{1}{c|}{ VIF } \\
\hline 1 & (Constant) & & \\
CI & .579 & 1.728 \\
H & .324 & 3.083 \\
& HXCI & .344 & 2.907 \\
\hline
\end{tabular}

Sumber: Hasil pengolahan data menggunakan SPSS

Berdasarkan Tabel 4 diatas, diperoleh hasil VIF lebih kecil dari 10 maka dapat disimpulkan bahwa tidak terdapat multikolinieritas antar variabel independen.

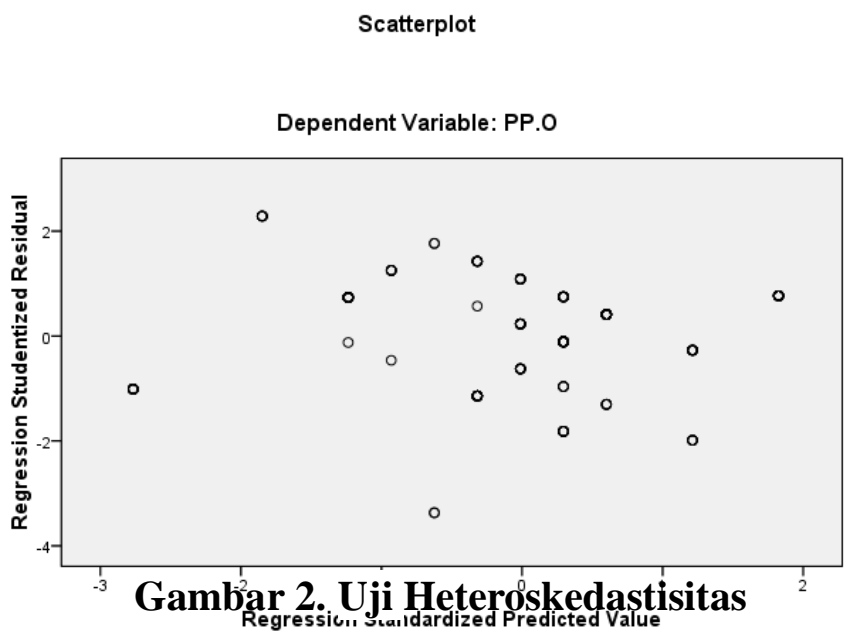

Berdasarkan Gambar 4.2 diatas, dapat dilihat bahwa titik-titik menyebar di atas dan di bawah angka 0 pada sumbu $\mathrm{Y}$, sehingga dapat disimpulkan bahwa tidak terjadi heteroskedastisitas.

Uji Regresi Linier Berganda

Tabel 5

Hasil Uji Regresi produk Samsung

\begin{tabular}{|c|c|c|c|c|c|c|}
\hline \multirow{2}{*}{\multicolumn{2}{|c|}{ Model }} & \multicolumn{2}{|c|}{ Unstandardized Coefficients } & \multirow{2}{*}{$\begin{array}{c}\text { Standardized } \\
\text { Coefficients }\end{array}$} & \multirow[b]{2}{*}{$\mathrm{t}$} & \multirow[b]{2}{*}{ Sig. } \\
\hline & & $\mathrm{B}$ & Std. Error & & & \\
\hline \multirow[t]{4}{*}{1} & (Constant) & -3.005 & .748 & & -4.018 & .000 \\
\hline & $\mathrm{CI}$ & .141 & .036 & .279 & 3.864 & .000 \\
\hline & $\mathrm{H}$ & .414 & .034 & .962 & 12.150 & .000 \\
\hline & $\mathrm{HxCI}$ & -.004 & .001 & -.320 & -2.791 & .006 \\
\hline
\end{tabular}

a. Dependent Variable: PP

Sumber: Hasil pengolahan data menggunakan SPSS

Berdasarkan Tabel 5 diatas menunjukkan bahwa persamaan regresi yang digunakan dalam penelitian ini adalah: $\mathrm{Y}=-3,005+0,141 \mathrm{X}+0.414 \mathrm{Z}+(-0,004) \mathrm{X} * \mathrm{Z}$ 
Tabel 6

Hasil Uji Regresi produk Oppo

Coefficients $^{\mathrm{a}}$

\begin{tabular}{|c|c|c|c|c|c|c|}
\hline \multirow{2}{*}{\multicolumn{2}{|c|}{ Model }} & \multicolumn{2}{|c|}{ Unstandardized Coefficients } & \multirow{2}{*}{$\begin{array}{c}\text { Standardized } \\
\text { Coefficients }\end{array}$} & \multirow[b]{2}{*}{$\mathrm{t}$} & \multirow[b]{2}{*}{ Sig. } \\
\hline & & $\mathrm{B}$ & Std. Error & & & \\
\hline \multirow[t]{4}{*}{1} & (Constant) & -7.527 & 1.559 & & -4.829 & .000 \\
\hline & CI.O & .793 & .100 & 1.485 & 7.930 & .000 \\
\hline & H.O & .395 & .086 & .902 & 4.591 & .000 \\
\hline & HxCI.O & -.022 & .005 & -1.443 & -4.390 & .000 \\
\hline
\end{tabular}

a. Dependent Variable: PP.O

Sumber: Hasil pengolahan data menggunakan SPSS

Berdasarkan Tabel 6 diatas menunjukkan bahwa persamaan regresi yang digunakan dalam penelitian ini adalah: $\mathrm{Y}=-7,527+0,793 \mathrm{X}+0.395 \mathrm{Z}+(-0,022) \mathrm{X} * \mathrm{Z}$

\section{Perbandingan Samsung dan Oppo}

Dari pembahasan dan hasil yang telah didapat dari perhitungan menggunakan SPSS, maka dapat disimpulkan perbandingan antara produk Samsung dan Oppo yang akan dijelaskan dibawah ini:

1. Dari nilai $\mathrm{R}$ Square yang sudah dihitung di subbab sebelumnya, dapat dilihat perbandingan antara Samsung dan Oppo. Nilai R Square Samsung sebesar 75,2\% lebih unggul dibandingkan dengan Oppo yang hanya 59,5\%. Hal ini menunjukkan bahwa pengaruh variabel country image dan harga terhadap product preference lebih besar untuk Samsung daripada Oppo.

2. Dari pembahasan uji F yang telah dijelaskan di subbab sebelumnya, dapat dilihat bahwa hasil F hitung Samsung sebesar 198,246 dan hasil F hitung Oppo sebesar 95,808 dan memiliki signifikansi yang sama yaitu sebesar 0,000 yang menunjukkan bahwa $\mathrm{F}_{\text {hitung }}>$ $F_{\text {tabel }}(198,246>3,04)$ untuk Samsung dan $F_{\text {hitung }}>F_{\text {tabel }}(95,808>3,04)$ untuk Oppo. Dari hasil ini disimpulkan bahwa secara simultan (berganda) country image, harga dan moderasi harga untuk produk Samsung dan Oppo sama-sama mempunyai pengaruh positif dan signifikan terhadap product preference, sehingga menghasilkan kesimpulan Ha diterima dan Ho ditolak.

3. Berdasarkan hasil uji hipotesis secara parsial (uji t) yang telah dijelaskan di subbab sebelumnya didapat hasil sebagai berikut:

a. Pengujian variabel country image

t hitung variabel country image untuk Samsung sebesar 3,846 dan Oppo sebesar 7,930. Dari hasil tersebut dilihat bahwa nilai t Oppo lebih besar dari Samsung maka disimpulkan country image Oppo lebih menjadi pilihan. Untuk kedua produk ini sama-sama memiliki hasil $\mathrm{t}$ hitung $>\mathrm{t}$ tabel dengan nilai $\mathrm{t}$ tabel $=1,65263$ maka disimpulkan bahwa Ho ditolak artinya secara parsial ada pengaruh signifikan antara Country Image dengan Product Preference.

b. Pengujian variabel harga

t hitung variabel harga untuk Samsung sebesar 12,150 dan Oppo sebesar 4,591. Dari hasil tersebut dilihat bahwa nilai t Samsung lebih besar dari Oppo maka disimpulkan harga Samsung lebih menjadi pilihan. Untuk kedua produk ini sama-sama memiliki hasil $\mathrm{t}$ hitung $>\mathrm{t}$ tabel dengan nilai $\mathrm{t}$ tabel $=1,65263$ maka disimpulkan bahwa Ho 
ditolak artinya secara parsial ada pengaruh signifikan antara Country Image dengan Product Preference.

c. Pengujian variabel moderasi harga

t hitung variabel moderasi harga untuk Samsung sebesar -2,791 dan Oppo sebesar 4,390. Untuk kedua produk ini sama-sama memiliki hasil $t$ hitung $<\mathrm{t}$ tabel dengan nilai t tabel $=-1,65263$ maka disimpulkan bahwa Ho ditolak artinya secara parsial moderasi harga kurang berpengaruh signifikan antara Country Image dengan Product Preference.

\section{Kesimpulan}

Berdasarkan pembahasan dan hasil analisis data pada bab sebelumnya, maka kesimpulan yang dapat ditarik dari penelitian ini adalah :

b. Dari hasil pengujian hipotesis pertama dapat diketahui bahwa country image mempunyai pengaruh positif terhadap product preference.

c. Dari pengujian hipotesis yang kedua dapat diketahui bahwa harga berpengaruh terhadap product preference.

d. Dari hasil pengujian hipotesis ketiga dapat diketahui bahwa peran moderasi harga dapat memperkuat atau memperlemah product preference

\section{Saran}

Berdasarkan hasil penelitian ini, peneliti akan memberikan beberapa saran yang sekiranya dapat bermanfaat bagi peneliti selanjutnya dan perusahaan lain. Saran bagi penelitian selanjutnya diharapkan dapat memperbanyak sampel penelitian sehingga dapat memberikan hasil yang lebih baik lagi dan juga diharapkan dapat mengembangkan penelitian ke dalam industri-industri lain untuk mengetahui apakah variabel yang sama dibandingkan dengan variabel lainnya dapat memberikan hasil yang sama.

Penelitian selanjutnya juga diharapkan dapat menambahkan variabel dan metode yang berbeda untuk dapat mengetahui hasil dari setiap perbedaan metode dan mengembangkan metode yang telah ada.

\section{Daftar Pustaka}

Anderson. (2014). Statistics for Business and Exonomics $12^{\text {th }}$ Edition. International Edition. South-Western: Cengage Learning.

Andriani, Rikke (2015) Pengaruh Negara Asal (Country of Origin), Merek dan Reputasi Merek terhadap Loyalitas Merek.(Studi Pada Produk Kosmetik di Daerah Istimewa Yogyakarta.)

Camila, C., Jorge, C., and Rafael, G. (2016). Country Image Effect on Product Assesment: Moderating Role of Consumer Nationality.Review of Business Management, Sao Paulo, Vol. 18, No. 59, p.24-42.

David, C.S. (2014). Price in International Marketing. Esic Editorial.

Kotler, Philip, (2008). Manajemen Pemasaran. Edisi Milenium diterjemahkan Benyamin Molan, PT. Prehallindo, Jakarta

Kotler, P. and Gary. A. (2011). 10 ${ }^{\text {th }}$ Edition. Marketing Introduction. Indonesia: Pearson

Mehmet, D,. Sunil, S., and Kamel, M. (2010). Country Image and Consumer Preference for Emerging Economy Products: the Moderating Role of Consumer Materialism. International Marketing Review. Vol 27, No 2, pp. 141 - 163.

M. Fardan A.F, Suharyono, dan M. Kholid Mawardi. (2016). Analisis Citra Merek Berdasarkan Country of Origin (Studi Tentang Citra Merek Smartphone Asal Amerika Serikat Dan Asal China Pada Mahasiswa Universitas Brawijaya). Jurnal Adminitrasi Bisnis Vol. 19 No.1, 42-50 
Nizar, Frank and Marie. (2011). Marketing high-tech Products in Emerging Markets: The Differential Impacts of Country Image and Country-of-Origin's Image. Journal of product \& Brand Management. Vol. 20, Iss: 5, pp. 356-367.

Sugiyono. (2014). Metode Penelitian Bisnis. Alfabeta: Bandung.

Yasin, N.M., Noor, M.N., and Mohamad, O. (2007). Does Image Of Country Of Origin Matter To Brand Equity?. Journal Of Product And Brand Management. Vol.6, pp. 3848. 


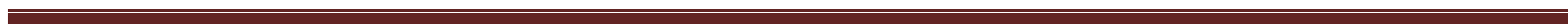
$\cdot$ 